\title{
İslam Hukukunda İstihlâk ve Hükümleri
}

\section{Yunus Naci CIBIZ *}

\section{Özet}

Modern insanın ihtiyacı olan günlük gıda, ilaç ve kozmetik maddeleri tabiî ve helal yollardan ancak \% 20 nispetinde imal edilebilmektedir. Aradaki açık, sanayi tipi imalat ile kapatılabilmektedir. Sanayi tipi üretim ise, karşımıza binlerce çeşit gıda katkı maddesini çıkarmaktadır. Bununla beraber gıda, (hususiyle gazlı meşrubatlar) kozmetik ve ilaçta kullanılan alkolün vaziyeti de helallik ve haramlık hususlarında dikkat çeken diğer bir meseledir. Yine günümüz meselelerinden olan hayvanî menşei belli olmayan peynir mayası ve kimyasal mayaların durumu ise araştırılması gereken bir diğer mevzudur. Meselenin iyi kavranabilmesi ve anlaşılabilmesi için ise fikıh kitaplarımızdaki istihlâk kavramını ve çerçevesini, ayrıca istihlâk ile alakalı verilen fetvaları iyi anlamak gerekmektedir.

Anahtar kelimeler: Helal Gıda, İstihlâk, Gıda Maddesi, Sağlık, Fiziksel Dönüşüm

\section{Istihlak and Their Judgements in Islamic Law}

\section{Abstract}

Nowadays people are in need of organic, natural and helal ingredients inside daily food, pharmacy and cosmetics products. Only $20 \%$ of products are manufactured accordingly. The solution for such a gap is industrial manufacturing. When it comes to the industrial production, it is obvious that many varieties of food additives are used within production. Another issue that should be considered is 'haram' and 'helal' for the reason alcohol is used within food, pharmacy and cosmetics products. What's more, deeper research is required when it comes to use of non-animal derived rennet. In order to solve such misunderstanding, it is necessary to reconsider the 'fatwas' related to the concept and framework of 'excise' (istihlâk) from the 'fiqh' literature.

Key words: Halal Food, Excise, Food, Health, Physical Transformation

Yalova Üniversitesi, Sosyal Bilimler Enstitüsü, Temel İslam Bilimleri, Yüksek Lisans Öğrencisi, yunuscibiz@gmail.com. 


\section{$226 \cdot$ YALOVA SOSYAL BILIMLER DERGISI}

\section{Giriş}

Modern insanın ihtiyacı olan gıda, ilaç ve kozmetik maddeleri tabiî ve helal yollardan ancak \% 20 nispetinde imal edilebilmekte iken aradaki açık, sanayi tipi üretimle kapatılabilmektedir. Sanayi tipi üretim ise, hammadde olarak genetiği değiştirilmiş organizmalar olarak bilinen GDO'lu mamulleri karşımıza çıkarmaktadır. Bunun sonucunda sekiz bin çeşit katkı maddesi ile karşı karşıya gelinmiştir. ${ }^{1}$ Baş döndürücü bir hızla çoğalmakta olan bu maddeler karşısında hangi maddenin helal, hangisinin haram olduğu, hangisinin ana maddesinin ne olduğu, bunların nasıl bir dönüşüm ve değişime uğradığı gibi mevzuları tespit işi hayli karışık bir hal almıştır. $\mathrm{Bu}$ meseleyi çözebilmek için fıkıh kitaplarımızdaki "İstihlâk" kavramını ve çerçevesini iyi anlamak ve yorumlamak lazımdır. Muasır bir mesele olan İstihlâk klasik fikıh kitaplarımızdan ziyade günümüz fikıh eserlerinde tartışılmış ve yorumlanmıştır. Bunun yanı sıra klasik eserlerimizde geçen temiz suya karışan bir damla kan veya şarabın hükmü gibi mevzular istihlak meselesine misal teşkil edebilmektedir.

\section{1. İstihlâk ve Mahiyeti}

\section{a. İstihlakin Lugavî ve Istılâhî Manaları}

İstihlâk (yoğaltım), lugatta helak olmak, ölmek manasına gelen h-l-k kökünden türemiş, bir malı infak etmek, harcamak, bir maddenin diğer bir maddeye kendisinden eser kalmayacak şekilde karışması manalarına gelmektedir. $^{2}$

Istılahta ise tüketim, faydalı bir şekilde harcama manasına gelen, istihsal mukabilinde kullanılan borçlar hukuku terimi olup, fikıhta da umumî kullanımı daha ziyade bu manasıyladır. İstihlâk fikıhta bu manası haricin-

1 Orhan Çeker, İstihale, I. Ulusal Helal ve Sağlıklı Gıda Kongresi, Sözlü Bildiriler, 19-20 Kasım 2011, Ankara, ed. Fatih Gültekin, Ankara, 2011, 102-125, 103.

2 İbn Manzûr, Ebû'l-Fadl Cemaluddin Muhammed b. Mükerrem el- Ensârî, Lisânü'l-Arab, (h-l-k) Maddesi, (Kâhire: Dâru'l-Maârif, 1119/1707), VI, 4686; Firuzâbâdî, Ebû't-Tâhir Mecdüddin Muhammed b. Yakub Firuzâbâdî, el-Kâmûs'ul-Muhît, h-1-k Maddesi, haz. Enes Muhammed eş-Şamî, Zekeriya Cabir Ahmed, (Kahire: Daru'l-Hadis, 1429/2008), 1804.

YIL: 5 SAYI: 9 
de İstihâle ile beraber taharet bâblarında zikredilmiş ve temiz kılıcı olarak istihlâkten bahsedilmiştir.

Klasik fikıh edebiyatımızda İstihlâk, bir maddenin, mevcudiyetini devam ettirse bile çok miktardaki bir madde içerisinde kaybolması demektir. İstihlakte mühim olan haramlık illetidir. İlletin, iz ve tesirin veya renk, tat ve kokunun bulunup bulunmaması gibi, ortadan kalkması ile haramlı̆̆ın kalktığına, illetin devamı halinde ise haramlığına hükmedilmesidir. ${ }^{3}$

İstihlâkte dikkat edilecek en mühim kıstas ise, kesret mevzuudur. İstihlake uğrayan maddenin çoklukla mı yoksa karıştığı maddenin yoğunluğu ile mi değiştiğidir. Her ne kadar klasik fikıh kitaplarımızda bazı miktarlar zikredilse de, istihlakte değişimi gerçekleştiren unsurun miktar değil tesir olduğudur. Bir diğer ifade ile istihlakte belirleyici unsur kemiyet değil keyfiyettir.

İstihlâke çağdaş araştırmacılar tarafindan iki anlam yüklenmiştir, bunlardan birincisi, bir necasetin özünün ilave edildiği temiz madde içerisinde renk, tat ve kokusundan eser kalmayacak şekilde kaybolmasıdır. ${ }^{4}$ İkinci mana ise, bir maddenin diğer bir maddeye mevcut sifat ve hususiyetlerini kaybedecek şekilde, necis maddenin içinde kalması ile beraber yok olmuş sayılabilecek şekilde karışmasıdır. ${ }^{5}$

İstihlak ayrıca "Haram veya necis bir maddenin galip olan helal madde içine karışarak tat, koku ve renk cihetinden kaybolmasıdır." şeklinde tarif edilmiştir. ${ }^{6}$

3 Murat Şimşek, İslam Hukuku Açısından Karışımlarda Ístihlak, Uluslararası 2. Helal ve Sağlıklı Gıda Kongresi, 7-10 Kasım 2013, (Konya: Aybil Yayınları, 2013), 401414, 403.

4 Bâhamd b. Muhammed Erfîs, İstihlâkü'l-A'yânü'n-Necise fî̀ Tasni'ıl-Gızâl, Unmûzecani li Dirâset'il- Infeha ve'l- Cîlâtîn http://www.islamfeqh.com/Nawazel/ NawazelItem.aspx?NawazelItemID=2028 (24 Ağustos 2014'te girildi).

5 Nezih Hammad, el-Edviyet'ul-Müstemile 'ale'l-Kûhul ve'l-Muhadderât, Mecelletü Mecma'1l- F1khi'l-İslâmî, Yı1:14, Say1:16, 79. Benzer bir tarif de şu şekildedir: İstihlak, bir maddenin kendisinden çok olan diğer bir maddeye karışarak onun içinde varlığını sürdürmekle beraber rengini, tadını ve kokusunu kaybetmesidir. Bkz. Nezih Hammad, el-Mevâddü'l-Muharreme ve 'n-Necise fi'l-Giza ve'd-Devâ beyne 'n-Nazariyye ve't-Tatbîk, Dimaşk, 2003, 26.

6 İbtisam el-Matrafî, et'Tedâvi bi'l-Muharramât, es-Sicillü'l-İlmî li Mü’tmer el-FıkYIL: 5 SAYI: 9 


\section{$228 \cdot$ YALOVA SOSYAL BILIMLER DERGISI}

\section{b. İstihlâkin Mahiyeti}

Az olan necis maddenin çok olan temiz madde içerisinde renk, koku ve tattan eser kalmayacak şekilde kaybolması manasına gelen istihlâke (yoğaltım) dayanak olarak bazı küllî kaideler gösterilmektedir, bunlar; "Eşyada asıl olan ibâhadır", "Haramlık ve necis olmak arızîdir." ve "Nadir olan yok hükmündedir.” küllî kaideleridir. Bu küllî kaideler sırasıyla, bir maddenin haram olmasının aslî değil arızî olduğu, az olan bir maddenin yok hükmünde addedileceği ve bir maddenin aslının ibâha (haram olmamak) olduğunu ifade etmektedir.

Yapılan tariflerden anlaşılan ve tariflerde dikkat çekilen noktalar şöyle siralanabilir;

- İstihlâkin vukuu için helal ve temiz olan madde, haram veya necis maddeden oran olarak çok olmalıdır.

- $\quad$ Bu kesret, az necis maddenin vasıflarını kaybettirecek derecede olmalidir.

- Necis maddenin mevcudiyeti veya ademi mevcudiyeti maddenin temiz veya necisliği ile alakalı belirleyicidir.

- Necis maddenin mevcudiyeti, vasıflarını kaybetmesi ile beraber olmalidir.

Bazı araştırmacılar aynı olmadıkları halde mevzunun girift olması ve benzerlik sebebiyle İstihlâki istihalenin bir cüz'ü veya müşabihi olarak görmüş ve öyle değerlendirmiştir. İbn Hazm (ö.456/1063) ve İbni Teymiye (ö.728/1328) bu araştırmacılar arasında zikredilebilir. ${ }^{7}$

hi'l-İslâmi's-Sani, Kazâya Tıbbiyye Muâsıra, Camiatü'l-İmam Muhammed b. Suûd'il-İslamiyye, Riyad, 1431/2009, I, 884. Ayrıca istihlâki benzer şekilde, az olan necis maddenin helal olan çok maddeye karışması sonrası helal maddenin az olan necis maddeye galip gelerek tat, koku ve renk olarak temiz bir hale gelmesi, şer'i haramlığının ve necasetinin izale olmasıdır. Şeklinde tarif edenler de olmuştur. Bkz. el-Matrafî, et'Tedâvi bi'l-Muharramât, I, 885.

7 İbni Hazm ez-Zâhirî, Ebû Muhammed Ali b. Ahmed b. Said b. Hazm, el-Muhalla fi Şerhi'l-Mücella bi'l-Hucec ve'l-Asar, haz. Hassan Abdulmennan, (Riyad: Beyt'ul-Fikri'd-Devliyye, t.y.), 97; İbn Teymiye, Ahmed b. Abdulhalim, Mec- 
Yine istihlâk'i istihâlenin bir nevi olarak zikreden ve dört kısımda toplayan Vehbe Zuhaylî İstihlâki şöyle açıklamıştır;

İstihlâk-i Zâtî, necis yağdan yapılan sabunda olduğu gibi tam bir değişikliğe uğrama.

İstihlâk-i Fenâî, kan ve bevil gibi necis maddenin temiz madde içerisinde kaybolması ve kendisinden eser kalmaması, insan kılından elde edilen proteinin diğer madde içinde kaybolması gibi.

İstihlâk-i bi'l-Mükâsere, necis olan maddeye suyun galip gelmesi. F1kıh kitaplarımızda mutlak suyun temiz ve temizleyici olduğu ifade edilmektedir. Buzâa hadisi ${ }^{8}$ buna delil olarak gösterilmektedir, Peygamber Efendimiz'e (sav) bu kuyunun içerisinde insan ve köpek pisliği bulunduğu söylenildiğinde "Su temizdir onu hiçbir şey kirletemez"9 buyurmaktadır. Hz. Enes'ten (ra) rivayet edilen diğer bir Hadis-i Şerifte ise; "Bir bedevî kalktı ve mescidin bir tarafına bevletti. Oradakiler ona bağrıştılar. Peygamber efendimiz (sav) onlara "onu bırakın" buyurdu. Bedevî işini bitirdikten sonra Efendimiz (sav) bevlettiği yere bir kova su dökülmesini emretti" ${ }^{10}$ buyrulmaktadır. Bu Hadis-i Şerifler suyun az veya çok olmasına bakılmaksızın suyun pislenmediğine delil olarak getirilmiştir. ${ }^{11}$

Ancak fikıh kitaplarımızda suyun az olması durumunda temiz olmaması, çok olduğunda ise temiz olması ifade edilmektedir. Çokluk için ölçü ise her mezhepte farkl1lık göstermektedir. Hanefî mezhebinde çokluk ölçütü şu şekildedir: Durgun su bir tarafından hareket ettirildiğinde diğer

mû'ul-Fetâvâ, haz. Abdurrahman b. Muhammed b. Kasım ve İbnuhu Muhammed, (Medine: Mücemmeı'l-Melik Fahd li Tabaati'l-Mushafi'ş-Şerif, 1425/2004), XXI, ss 501-502, 513.

8 Medine-i Münevvere'de Mescid-i Nebevî'nin kuzey batısında, Benî Saîde sakifesine (sofa, gölgelik) yakın, altı zira büyüklügüünde bir kuyu. https://www.google. com/maps/place/24\%C2\%B028'17.0\%22N+39\%C2\%B036'27.1\%22E/@24.46713 $1,39.607726,1103 \mathrm{~m} /$ data $=! 3 \mathrm{~m} 1 ! 1 \mathrm{e} 3 ! 4 \mathrm{~m} 2 ! 3 \mathrm{~m} 1 ! 1 \mathrm{~s} 0 \mathrm{x} 0: 0 \mathrm{x} 0$ ?hl=tr-TR $(26.09 .2014$ 'te girildi.). Ayrıca ayrıntılı bilgi için bkz. http:/www.taibanet.com/showthread. php?t=15121 (26.09.2014'te girildi.).

9 Nesâi, Miyâh,1; Tirmizî, Tahâret, 46.

10 Buhârî, Vudû, 57.

11 Vehbe Zuhaylî, Kadâyâ'l-Fıkh Ve'l-Fikr'il-Musâır, 1. bs., Dımaşk, Dar'ul-Fikr, 2006, 72 . 
tarafa hareketin ulaşmaması halinde suyun çok olduğuna hükmedilmektedir. $^{12}$

Şafî̂ ve Hanbelî mezhebi ise suyu, "Su, iki kulle olduğu zaman pislik taşımaz"13 Hadis-i Şerifini delil getirerek iki kulle ${ }^{14}$ suyun çok su olduğuna hükmetmişlerdir.

Zâhirîler ise; pis yağ hariç suyu hiçbir şeyin kirletmeyeceği görüşündedirler. ${ }^{15}$

Zuhayli'ye göre istihlakin dördüncü kısmı ise İstihlâk bit'Tasnî'dir. $\mathrm{Bu}$ necis maddenin istihâle ile temiz hale gelmesinden sonra söz konusu maddenin parçalanarak yeni madde elde etmek manasına gelmektedir. Ona göre bu kısım ile elde edilen madde temiz olmaktadır.

Yapılan araştırmalar istihlak ile istihalenin aynı olmadığını açıkça ortaya koymaktadır. Renk, koku ve tat özellikleri suyun temizliği için bir kıstas olarak fikıh kitaplarımızda mevcuttur. Bu kıstasla, mezkûr vasıfların bulunması ile mevzubahis maddenin temizliğine hükmolunmaktadır. Buradan anladığımız kadarıyla istihlâke (yoğaltım) uğrayan madde renk, koku ve tat olarak münasip durumda olduğunda temiz olarak addedilmektedir.

\section{2. İstihlâk ile İstihâle Terimleri Arasındaki Fark}

İstihlâk ile İstihâle her ne kadar bazı araştırmacılar tarafından aynı olarak ifade edilse veya istihlâk istihâlenin bir kısmı olarak anlaşılsa da, İstihâle ile İstihlâk birbirlerinden farklı iki fikıh terimidir.

12 İbn Hümâm, Kemalüddin Muhammed b. Abdülvahid, Fethu'l-Kadîr, Dâru'l-Fikir, t.y., I, 98.

13 Ebû Dâvûd, Tahâret, 33; Tirmîzî, Tahâret, 50.

14 Kulle; lügatta, kaldırıp taşımak, "Güçlü bir erkeğin taşıyabileceği su küpü” manasınadır. Istılâhta ise ihtilaflar olmakla beraber yaklaşık 160 kg ağırlığında su alan kabı, küpü ve o miktardaki suyu ifade etmektedir. Muhammed Ravvâs Kal'aci, $M u$ 'cemu Lugati'l-Fukahâ, 2. bs., (Beyrut: Dâru'n-Nefâis, 1988), "Kulle” Maddesi, 275. Ayrıca teferruatlı bilgi için bkz. Cengiz Kallek, "Kulle”, TDV İslam Ansiklopedisi (DİA), XXVI, 357.

15 İbn Hazm, El-Muhallâ, 99.

YIL: 5 SAYI: 9 
İstihlak daha evvel tarifleri yapıldığı üzere, haram veya necis maddenin kendisinden fazla olan temiz bir madde içerisine karışarak mevcudiyetini devam ettirmekle beraber renk, tat ve koku olarak temiz madde gibi olmasidır.

İstihale ise lugatte; "Hvl" kökünden türemiş İnkılab, değişim, dönüşüm, çarpıtmak, muhal olmak, vücûdu ve meydana gelmesinin mümkün olmaması, bir şeyin sıfat ve zatının değişmesi manalarına gelmektedir. ${ }^{16}$ Istılahta ise, "Bir hakikatin diğer bir hakikate dönüşmesidir" ${ }^{17}$ şeklinde tarif edilmiştir.

İstihaleyi umumî hatlarıyla şöyle ifade etmek doğru olacaktır; necis bir maddenin kimyevî, biyolojik ve benzeri müessirlerle bulunduğu halden zit bir hale dönüşmesidir. İstihale, iyiye ve kötüye olabilir; temiz olan bir yemeğin midede sindiriminden sonra ortaya çıkan posası necistir ki kötüye olan istihaleye misal olarak bu zikredilebilir. Necis olan şarabın bazı tesirlerle sirkeleşmesi ve temiz olması, pis olan tezeğin yanıp küle dönüşmesi ve bu külün temizlikte kullanılması iyiye olan istihaleye misal olarak verilebilir.

İstihâle, istihlâkten şu noktalarda ayrılır; evvela istihlâk fiziksel bir hadise iken istihâle kimyasal bir hadisedir. İstihlâk, bir maddenin diğer madde içerisinde kaybolması ve bunun neticesinde elde edilen necis veya temiz olmayı ifade ederken, istihâle bir maddenin tek başına olduğu halden başka bir hale dönüşümünü ifade etmektedir.

İstihâle akabinde madde, olduğu halden mahiyet ve yapı bakımından evvelkinden farklı bir hale gelirken, İstihlâkte zahiren bir kaybolma olsa bile maddenin aslında bir değişiklik meydana getirip getirmediğine bakılmamaktadır.

16 İbn Manzûr, Lisânü'l-Arab, (h-v-1) Maddesi, II, 1055; Ahmed b. Muhammed b. Ali el-Feyyumi el-Magri, El-Misbah el-Munir, (h-v-l) Maddesi, (Lübnan: Mektebetü Lübnan, 1987), 60.

17 İbn Âbidin, Muhammed Emin b. Ömer b. Abdülaziz Âbidin, Reddü'l-Muhtâr ale'd-Dürr'i-lMuhtar, 2. bs, (Beyrut: Dâru'l-Fikr, 1412/1992), I, 327. 


\section{Fıkhî Mezheplerde İstihlâk ve Fıkıh Kitaplarındaki Fetva Misalleri}

İstihlâk'e hadis kitaplarımızın taharet, eşribe, et'ıme, yemin, radaa ve kefaret gibi bab ve bölümlerinde, fikıh literatürümüzün taharet, yemin, radaa, ruhûn ve bey' gibi kısımlarında rastlamak mümkündür. Klasik fikıh eserlerimizde birebir 1stilâhî manadaki istihlâk kelimesi ile karşılaşmasak da bir şeyin diğerine galip gelmesi, bir maddenin diğerine karışması ve içine karıştığı maddeden ayrılamaması gibi ifadeler sıklıkla kitaplarımızın alakalı bahislerinde yer almaktadır.

İstihlak, İmam-1 Â'zam Ebû Hanîfe (ö.150/767) (rh) ${ }^{18}$, İmam-1 Ahmed bin Hanbel (ö.240/855) (rh) ${ }^{19}$, Malikî mezhebinden bir kavil ${ }^{20}$ ve Zahirîle$\mathrm{re}^{21}$ göre fikılh kitaplarından anlaşıldığ 1 üzere temizleyici bir sebep olarak zikredilmiştir.

Şafî̀ ve Hanbelî mezhepleri ise genel olarak istihlâkin temizleyici olduğunu ifade etmeseler de daha evvel de izah edildiği üzere mevzu ile alakalı Hadis-i Şeriflere ${ }^{22}$ dayanarak istihlâkin temizleyici olduğuna kail olmuşlardır.

Klasik fikıh kitaplarımızda istihlâk ile alakalı misaller umumiyetle istihâle başlığ 1 altında zikredilmektedir. Bu misallerin mühim olduğunu düşündüğümüz bazılarını aşağıda zikredilmiştir;

a. Temiz bir suya başka bir su karışsa bakılır, eğer renk ve tat olarak diğer su temiz suya galip gelmemiş ise sahih kavle göre o su ile abdest caizdir. ${ }^{23}$

18 İbn Nüceym, Zeynuddin b. İbrahim b. Muhammed b. Nüceym, el-Bahru'r-Râik Şerhu Kenzi'd-Dekâlk, 2. bs., (Dâru'l-Kitabi'l-İslâmî, ty.), I, 247.

19 İbn Kudâme el-Makdisî, Ebû Muhammed Muvaffikuddin Abdullah b. Ahmed, el-Muğnî li İbn Kudâme, (Kahire: Mektebetü Kahire, 1388/1968), I, 13.

20 Muhammed bin Ahmed ed-Dusûkî, Haşiyetü'd-Düsükî ala'ş-Şerhi'l-Kebîr, (Dâru'l-Fikr, t.y.), I, 56.

21 İbn Hazm, el-Muhallâ, 97.

22 Kulleteyn Hadis-i Şerifi; "Su, iki kulle olduğu zaman pislik taşımaz", Ebû Dâvûd, Tahâret, 33; Tirmîzî, Tahâret, 50.

23 Kâsânî, Alâuddin Ebû Bekir b. Mes'ûd b. Ahmed el-Kâsânî, Bedâiu's-Sanâi fi Tertibi'ş-Şerâi, (Dâru'l-Kütübi'l-İlmiyye, 1406/1986), I, 17; Mergınânî, Ali b. Ebi Bekr b. Abdulcelil el-Fergânî el-Mergınânî, el-Hidâye, haz. Talal Yusuf, (Beyrut: Dâru 
b. Temiz bir suya eti yenen hayvanların içtiği suyun artığı karışsa galebe ile amel olunur. ${ }^{24}$

c. Bir kimse kendisine az miktarda mâi müsta'mel (kullanılmış su) karışan temiz bir su ile abdest alsa burada galebe ile amel olunur. ${ }^{25}$

d. Bir yağa leş hayvanın erimiş iç yağı karıșsa ve ayırmak mümkün olmasa temiz yağ fazla olsa bile onu yemek caiz değildir. Ancak aydınlatmada veya bir nesneyi yağlamada kullanılabilir. Çoğa göre hüküm vermek zaruret anında veya özel durumlarda olur. $\mathrm{Bu}$ yağın çoğu temizdir diye tümüne temiz ve helal hükmü veremeyiz. Çünkü leş hayvanın yağı az da olsa ve diğer yağın içinde kaybolsa da o yağın içinde mevcuttur. ${ }^{26}$

e. Kendisi ile teyemmüm caiz olan bir toprağa kendisi ile teyemmüm caiz olmayan bir toprak karışsa bakılır, eğer teyemmüm kendisi ile caiz olan toprak fazla ise o toprakla teyemmüm caizdir. ${ }^{27}$

f. Necis su veya toprak birbirine karışsa ve çamur olsa, bakılır temiz olan fazla ise diğerine galip geleceği için temizdir. ${ }^{28}$ Bu toprak ile kap yapılsa bu kapta yapılan yemek temizdir.

g. Bir kişi ben süt içmeyeceğim diye yemin etse, içerisine süt damlamış bir suyu içse süt yok hükmünde olduğundan yemini bozulmuş olmaz. ${ }^{29}$

İhyâi’t-Türasi'l-Arabî, t.y.), I, 4; Ebû'l-Mealî Burhanuddin Mahmud b. Ahmed b. Abdulaziz b. Ömer b. Mâze el-buhârî, el-Muhıtu'l-Burhânî fi'l-Fıkhi'n-Numânî Fıkhı'l-Imamı Ebî Hanîfe Radıyallâhu anh, haz. Abdulkerim Sâmî el-Cundî, 1. bs., (Beyrut: Dâru'l-Kütübi'l-İlmiyye, 2004/1424), I, 119; Ebû Muhammed Mahmud b. Ahmed b. Musa Bedruddin, Minhatu's-Sülûk fî Şerhi Tuhfetu'l-Mülûk, haz. Ahmed Abdurrezzâk, 1. bs., (Katar: Vüzerâti'l-Evkâf ve'ş-Şüuni'l-İslâmiyye, 2007/1428), 39; Mâverdî, Ebû'l-Hasan Ali b. Muhammed b. Muhammed el-Maverdî, el-Hâvi’l-Kebir fî Fıkhi Mezhebi İmami'ş-Şafî̀ Şerhu Muhtasarı'l-Müzenî, haz. Şeyh Ali Muhammed, 1. bs., (Beyrut: Dâru'l-Kütübi'l-İlmiyye, 1419/1999), I, 47

24 Tahtâvî, Ahmed b. Muhammed b. İsmail et-Tahtâvî, Hâşiyetü 't-Tahtâvî alâ Merâkı'l-Felâh Şerhu Nûri'l-Îzâh, haz. Muhammed Abdülaziz el-Hâlidî, 1. bs., (Beyrut: Dâru'l-Kütübi'l-İlmiyye, 1997/1418), 31.

25 Kâsânî, Bedâiu's-Sanâî, I, 68.

26 Serahsî, Muhammed b. Ahmed b. Ebî Sehl Serahsî, el-Mebsût, (Beyrut: Dâru'lMarife, 1414/1993), I, 203.

27 Ebû Bekir b. Ali b. Muhammed el-Haddâdî, el-Cevheretü'n-Neyire, 1. bs. Matbaatu'l-Hayriyye, 1322, I, 23.

28 İbn Âbidîn, Reddü'l-Muhtâr, I, 324.

29 Mergınânî, el-Hidaye, I, 218. 


\section{$234 \cdot$ YALOVA SOSYAL BILIMLER DERGISI}

h. Bir kişi şu sütten içmeyeceğim diye yemin etse sonra sütün tadı gidecek kadar çok bir suya karıştırılsa yemininde hânis olmaz. ${ }^{30}$

i. Bir kimse su kendisine galip gelen içkiyi içse kendisine had uygulanmaz. Çünkü su içkiye galip gelmiştir. ${ }^{31}$

j. Nebiz, şaraba karışsa ondan bir kişi içse ve sarhoş olmasa bakılır, eğer galip olan şarapsa had uygulanır. Eğer galip olan nebiz ise had uygulanmaz. ${ }^{32}$

k. Süte konulan ilaç mevzuunda çokluğa bakılır çokluk süt tarafında ise (radaâ) akrabalık tesis olur, ilaç çok ise akrabalık oluşmaz. ${ }^{33}$

1. İnsan sütüne ilaç karıştırılsa, ilaç sütün tat, koku ve renginden en az ikisine galip gelirse süt akrabalık tesis olmaz. ${ }^{34}$

m. Kadının sütü koyunun sütüne karışsa burada da çokluğa itibar olunur, galip olan süt hükmü belirler. ${ }^{35}$

30 Muhammed bin Ahmed b. Ebî Ahmed Ebû Bekir Alaüddin es-Semerkandî, Tuhfetü'l-Fukahâ, 2. bs., (Lübnan: Dâru'Kütübi' İlmiyye, 1414/1994), II, 319; Alâüddin Ebû'l-Hasan Ali bin Süleyman el-Merdâvi ed-Dımaşkî el-Hanbelî, el-İnsaf fì Marifetir-Râcihi mine'l-Hılâf, 2. bs., (Beyrut: Dâru İhyâi't-Türasi'l-Arabî, t.y.), IX, 337.

31 Kâsânî, Bedâiu's-Sanâî, V, 113; İbn Âbidîn, Reddü'l-Muhtâr, IV, 38.

32 Serahsî, el-Mebsut, XXIV, 20.

33 Serahsî, el-Mebsut, V, 140; Mergınânî, el-Hidaye, I, 218; Fahruddin ez-Zeylaî, Osman b. Ali el-Bâriî ez-Zeylaî, Tebyinu'l-Hakâlk Şerhu Kenzi'd-Dekâik, 1. bs., (Kahire: el-Matbaatü'l-Kübra el-Emiriyye, 1313), II, 185; Haskefî, Muhammed b. Ali b. Muhammed el-Maruf Alaüddin el-Haskefî el-Hanefî, ed'Dürrü'l-Muhtar Şerhu Tenvîri' '-Ebsar ve Câmiu'l-Bihar, haz. Abdülmun'im Halil İbrahim, 1. bs., (Lübnan: Daru'l-Kütübi'l-İlmiyye, 1423/2002), I, 203; Halef b. Ebi Kasım Muhammed el-Ezdî el-Kayrevânî el-Mâlikî, et-Tehzîb fí İhtisari'l-Müdevvene, haz. Muhammed Emin, 1. bs., (Dubai: Dâru'l-Buhus lid'Ddirâseti'l-İslamiyye ve İhyai't-Türas, 2002/1423), II, 451.

34 İbn Abdilberr, Ebû Ömer Yusuf b. Abdullah el-Kurtûbî, el-Kâfi fî Fikhi Ehli'l-Medine, haz. Muhammed Muhammed el-Moritânî, 2. bs., (Riyad: Mektebetu'r-Riyad el-Hadîse, 1400/1980), II, 540; Abdurrahman b. Muhammed b. Süleyman Şeyhîzade, Mecma'ul-Enhur fi Şerhi Mülteka'l-Ebhur, (Dâru İhyâi't-Türasi'l-Arabî, t.y.), I, 379; Abdülkadir b. Ömer b. Abdülkadir eş-Şeybânî, Neylü'l-Mearib bi Şerhi Delili t'-Talib, haz. Muhammed Süleyman Abdullah Aşkar, 1. bs. (Kuveyt: Mektebetü'l-Felah, 1403/1983), II, 286.

35 Mergınânî, el-Hidâye, I, 218; Bâbertî, İnâye, III, 451.

YIL: 5 SAYI: 9 
n. İnsan sütüne yabancı bir sıvı madde karışması halinde onu içen çocuk ile akrabalığın sübutunun hükmü, sütün veya karışan maddenin çokluğuna göre verilir. ${ }^{36}$

o. Bir kadının sütüne diğer bir kadının sütü karışsa onu içen çocuğun İmamı Şafii (ö. 204/820), İmamı Muhammed'e (ö.189/805) (rh) göre her iki kadınla da akrabalığı sabit olur. İmamı Yusuf ve İmamı Âzam'a göre, sütü galip olanla akrabalık sabit olur. ${ }^{37}$

p. Hanefîlere göre ona on kuyu veya havuz büyük sayılır ve temizdir, ${ }^{38}$ zira bu mevzuda Peygamber Efendimiz (sav) "Kim hayvanları için bir kuyu kazarsa kuyunun etrafından kırk zira onundur" 39 buyurmuşlardır.

q. Şafiî ve Hanbelîler "Su iki kule olduğunda pislik taşımaz temizidir." ${ }^{40}$ Hadis-i Şerifi delil ittihaz edilerek su iki kulle olduğunda temizdir hükmünü vermektedir.

r. İmam-1 Muhammed'den nakledildiğine göre; "Bir kişi yanındaki içkiden içmeyeceğine yemin etse, sonra da onu bir su kabına dökse, o kaptaki su içkiye galip gelse ve içkinin rengi kokusu ve tadı gitse ve daha sonra mevzu bahis şahıs bu suyu içse yemininde hânis olmaz.

36 Mergınânî, el-Hidâye I, 218; Fahruddin ez-Zeylaî, Tebyinu'l-Hakâlk, II, 185; Ahmed b. Muhammed b. Ali b. Hacer el-Heysemî, Tuhfetu'l-Muhtac fí Şerhi'l-Minhâc, (M1sır: Mektebetü'Ticâri el-Kübrâ, 1357/1983), VIII, 285; Mahfuz b. Ahmed b. Hasan Ebû'l-Hattab el-Kulûzânî, el-Hidâye alâ Mezhebi Ahmed bin Hanbel eş-Şeybânî, haz. Mâhir Yasin, 1. bs. (Müessesetü Ğaras lin-Neşr ve’t-Tevziğg, 1425/2004), 491; İbn Kudâme, Abdurrahman b. Muhammed b. Ahmed b. Kudâme el-Makdîsî el-Hanbelî, eş-Şerhu'l-Kebîr alâ Mütüni 'l-Mukni', haz. Muhammed Reşit Rıza, (Dâru'l-Kitabi'l-Arabî lin'Neşr ve't-Tevziğ, t.y.), IX, 205

37 Serahsî, el-Mebsut, V, 140; Kâsânî, Bedâiu's-sanâî, IV, 10; Bâbertî, Inâye, III, 454; Abdullah b. Mahmud b. Mevdud el-Mevsılî el-Beledhî Mecduddin Ebû'l-Fadl, el-İhtiyâr li Ta'lili'l-Muhtâr, eş-Şeyh Mahmud Ebû Dakıka, (Kahire: Matbaatu'l-Halebî, 1937/1356), III, 119; Abdulgani b. Talib b. Hımade b. İbrahim, el-Lübâb fi Şerhi'l-Kitab, haz. Muhammed Muhyiddin Abdulhamid, (Beyrut: Mektebetü'l-İlmiyye, t.y.), III, 35; İbn Hacer el-Heysemî, Tuhfetu'l-Muhtac, VIII, 286.

38 Mevsîlî, Abdullah b. Mahmud b. Mevdûd el-Mevsılî, Ihtiyar li Ta 'lili'l-Muhtar, haz. eş-Şeyh Mahmud Ebû Dekîka, (Kahire: Matbaatü'l-Halebî, 1356/1937), I, 14.

39 İbn Mâce, Ruhûn, 22, Dârîmî, Buyû, 82.

40 Ebû Dâvûd, Tahâret, 33; Tirmîzî, Taharet, 50; Nesâî, Tahâret, 52; İbn Mâce, Tahâret, 75. 
Çünkü başka maddenin kendisine galip gelmesi ile istihlake uğrayan şey yok hükmündedir. Nitekim hudutsuz miktarda suya dökülen içki ile izi kalmayacak şekilde istihlake uğramış necaset de aynı hükümdedir"41

\section{Günümüzde İstihlâke Mevzu Olan Bazı Meseleler}

İstihlak mevzuunda gıda ile alakalı günümüzde en çok tartışılan konulardan birisi peynir yapımında kullanılan mayalar ve yine modern insanın günlük hayatının bir parçası haline gelmiş bulunan gazlı meşrubatlardır. Bunun yanında kozmetik ve ilaçta kullanılan, az miktardaki haram maddenin vaziyeti de tartışma mevzuudur.

Peynir yapımında buzağı kursağından imal edilen mayalar kullanılmaktadır. Bu işlem zahmetli ve uzun bir süreci ihtiva etmektedir. Bu süreç sebebiyle günümüzde gelişen teknolojik imkânlarla buzağı midesine konakçı mikroplar gönderilmekte ve bu mikroplar daha sonra alınarak bunlar vasıtasıyla kimyasal mayalar üretilmekte veya ölü hayvan ve domuz gibi helal olmayan hayvanlardan elde edilen kursaklar kullanılmaktadır. Araştırmacılar konakçı mikrop yöntemiyle elde edilen mayanın kaynağının helal olması halinde bu mayanın helal olacağını ifade etmektedir. Kaynağın ölü hayvan kursağı veya domuz kursağı gibi helal olmaması durumlarında ise helallikten bahsetmek mümkün olmamaktadır.

İmam-1 Serahsî (rh) (ö.483/1090) peynir mayası ile alakalı şu malumatı nakletmektedir; İmam-1 Âzam Ebû Hanife'ye (rh) göre ölmüş hayvanın şirdeninden (ön mide) alınan maya sıvı veya katı olmasına bakılmaksızın süt hükmünde temiz bir maddedir. İmam-1 Şafî̂’ye (rh) göre necistir. İmam Ebû Yusuf ve Muhammed'e (rh) göre ise, şayet sıvı ise necis bir kaba konulmuş süt gibi necistir. Eğer katı ise yıkadıktan sonra kullanılmasında bir beis yoktur. Çünkü kabın necis olması onun içini necis yapmaz, dışına bitişenler ise yıkamakla giderilir. Çünkü o madde hayvan meyte iken maya veya süt olmuş değildir. Binaenaleyh koyunun ölmesi ona zarar vermez. ${ }^{42}$

İbn Âbîdîn (rh) (ö.649/1252) ise peynir mayasından şu sözlerle bahseder; maya süt emen oğlağın karnındaki şirdenden çıkan sarı bir

41 Kâsânî, Bedaiu's-Sanâi, V, 113.

42 Serahsî, el-Mebsût, XXIV, 28-29.

YIL: 5 SAYI: 9 
maddedir. Peynir yapımında kullanılır, oğlak sütten kesilip yemeye başlayınca şirden işkembe olur ve peynir mayası için kullanılamaz hale gelir. Bu hususta sahih görüş İmam-1 Âzâm'ın görüşüdür. Mültekâ isimli eserin sahibi şerhiyle beraber eserinde şu ifadelere yer vermektedir. "Ölmüş hayvanın mayası mâî bile olsa temizdir, sütü de böyledir. Yani usulüne münasip biçimde kesilmiş hayvan gibidir. İmameyn buna muhaliftir; çünkü onlara göre sıvı olan şirden mekâna muzaf olmakla necistir. Biz deriz ki; Mayanın çıtığı yerin pis olması, hayvanın sağlığında da bir etki meydana getirmez. Zira fışkı ile kan arasından çıkan süt temizdir. ${ }^{43}$

Hanefîler, bu tür peynirlerle alakalı olarak meyte hükmünde olması gereken mecûsîlerin kestikleri oğlak ve kuzuların şirdeninden yapılan mayayı örnek göstermişlerdir. Sahabe-i kirâm tarafından halkı mecûsî olan toprakların fethi sonrası o belde halkının imal ettikleri peynirleri yemeleri bu mesele de delil olarak getirilmiştir. ${ }^{44}$

Şafiîler, süt haricinde bir şey ile beslenmemiş ve İslâmî usûllere göre boğazlanmış hayvanların şirdeninden yapılan mayaların kullanımına cevaz verirken müteahhirîn Şafî̂ uleması zaruret gerekçesi ile bu tür mayaların da kullanılabileceğini söylemişlerdir. ${ }^{45}$

Muâsır araştırmacılar da mayalar hususunda iki görüşe ayrılmış durumdadır; Nezîh Hammad, Yusuf el-Kardâvî, Hamdi Döndüren, Suudî Arabistan Fetva Komitesi (el-Lecnetü'd-Dâime) ve İslam Tıp Birliği Örgütü sahabe fiiline, Faruk Beşer istihlâke, Hayrettin Karaman ise istihâleye istinaden meytenin şirdeninden yapılan mayanın kullanılmasını caiz görürken, Vehbe Zuhaylî, Bâhamd Erfîs gibi bu hususta araştırma yapmış kişiler ise ölmüş hayvan şirdeninden yapılan mayanın kullanılmasının caiz olmayacağı yönünde kanaat belirtmişlerdir.

Peynir mayaları ile alakalı dikkat edilmesi gereken bir diğer husus ise domuz kaynaklı mayalardır. Günümüzde peynir mayalarında mikrobiyel maya kullanımı oranı yüzde doksanları bulmaktadır. Buna rağmen peynir

43 İbn Âbîdîn, Reddü'l-Muhtâr, I, 206.

44 Serahsî, el-Mebsût, XXIV, 28.

45 Şirbînî, Şemsüddin Muhammed b. Ahmed el-Hatîb eş-Şirbînî, Muğnî'l-Muhtâc ilâ Marifeti Meâni Elfâzi'l-Minhâc, 1. bs., (Beyrut: Daru'l-Kütübi'l-İlmiyye, 1994/1415), VI, 156. 


\section{8 - YALOVA SOSYAL BILIMLER DERGISI}

mayalarının domuz kaynaklı olma ihtimali dikkatlerden kaçmamalıdır. ${ }^{46}$

Peynir mayaları mevzuunda istihlâk veya istihâle kuralının işletilmesi bir çözüm aracı olarak kullanılmaktadır. Muasır dönem fikıh araştırmacılarına göre bu hususta İmam-1 Âzam'ın (rh) görüşünün alınması geçiş döneminde bir kolaylık olması açısından fetvaya daha layık gözükmektedir.

Meşrubat ürünlerinde ise katkı maddelerini çözmek için az miktarda alkol kullanılması bu tür içecekleri tartışmalı hale getirmektedir. Tartışmanın temel noktası ise bu alkolün sarhoş edicilik vasfının bulunup bulunmadığ1 teşkil etmektedir.

Doğadaki meyve ve sebzelerde tabiî olarak ortaya çıkan alkol ile alakalı dinimizde bir nehiy bulunmamaktadır. Sarhoşluk meydana gelmediği müddetçe meşru addedilmiştir. Peygamber Efendimiz'in (sav) kişiyi sarhoş etmeyen nebize müsaade buyurmaları buna delildir. Ebu Mûsa elEş'arî ve Muâz (ra) Yemen'e gönderildiklerinde Peygamber Efendimize (sav) Yemen'de baldan yapılan bir nebiz (bit') ve darıdan yapılan bir nebiz (mizr) içildiğini bunlardan kendilerinin içip içemeyecekleri hususunu sual ettiler. Allah Rasûlü (sav) "Sarhoşluk vermiyorsa içebilirsiniz, çünkü ben her sarhoşluk vereni haram kıldım” buyurmuşlardır. Bununla beraber yenildiği, içildiği veya koklandığında sarhoşluk veren, insan aklını ve tefekkür melekesini ortadan kaldıran maddelerin haram olduğu kat'idir. ${ }^{47}$

46 Domuz özü itibariyle necistir. Domuzun haramlığı ile alakalı şunlar zikredilebilir; yapılan birçok araştırmaya göre domuz ve mamullerinin ishal, kusma, ateşli hastalıklar, cinsel isteksizlik, farklı sapık cinsel eğilimler, kalıtımsal ve genetik hastalık devri, akıl ve hafiza kaybı, fikrî ve psikolojik rahatsızlıklar, alzheimer, sara gibi birçok hastalığa yol açtığı görülmüştür. Ayrıca domuzun haramlığının illeti olmasına gerekte yoktur, nass tarafından bildirilmediği gibi akıl yoluyla da anlaşılmaya çalışılmasına ihtiyaç gözükmemektedir. Bu hususun taabbudî vechesi olduğu akıllardan çıkmamalı ve domuzun Ümmet-i Muhammed'in imtihanı olduğu göz ardı edilmemelidir.

47 Nesâi, Eşribe, 51 (Tefsiru'l-Bit' ve'l-Mizr) Ayrıca, Ebû Said el-Hudrî’nin (ra) naklettiği bir Hadis-i Şerifte Efendimiz (sav) "Sizden kim nebiz içerse, yalnız zebib veya yalnız temr içsin. Bunları birbiri ile karıştırmasın.” Buyurmuştur. Bk. Müslim, Eşribe, 5; Ebû Davud, Eşribe, 8; Nesâî, Eşribe, 51. Yine Hz. Aişe'den (ra) rivayet edilen bir diğer Hadis-i Şerifte "Ben Rasûlüllah'a kuru hurma şırası sunuyordum. Bunu tatlı bulmayarak içine kuru üzüm koymamı emretti, ben de öyle yaptım" buyurmuştur. Bk. Musannef İbni Ebî Şeybe, V, 80.

YIL: 5 SAYI: 9 
Şarap üzümden elde edilen ve kendisine "hamr" ismi verilen sarhoş edici vasıflı bir içecektir. Hamr'ın dışında başka maddelerden elde edilen diğer sarhoş ediciler mecazen ve kıyas yoluyla hamr'dır. Hamr aynen necis olmakla beraber mecazen hamr olan diğer sarhoş ediciler böyle değildir. ${ }^{48}$

Günümüzde gazlı içeceklerde alkol oranı gram esasına göre verilmektedir. Araştırmacılara göre hacim esasına göre hesaplanması durumunda daha makul ve daha yüksek bir miktarlar ortaya çıkmaktadır. Avrupa'da alkol miktarı hacme göre hesaplanmakta iken ülkemizde gram oranıyla yapılmaktadır. Ülkemizde de hacim esasına geçilmeli ve alkol oranı yüzde ile verilmesi gerekmektedir. Ayrıca alkollü içkilerin üzerinde alkol oranı yazılırken alkolsüz meşrubatların üzerinde alkol oranı verilmemektedir. Meşrubatlardaki alkol oranları da yüzde olarak ambalaj üzerinde verilmelidir.

Türkiye'de on gazlı içecek üzerinde yapılan bir çalışmada ${ }^{49}$ alkol nispetlerinin yüzde sıfir ile bir elli altı (\% 0 ile \% 1,56) arasında değiştiği gözlemlenmiştir. ${ }^{50}$ Etil alkol bu içeceklerde esans için ara çözücü olarak kullanılmaktadır. Gazlı içeceklerin içerisindeki alkol miktarı sarhoş edecek hadde ulaşmıyorsa istihlâk ile helal olacağı üzerinde durulmuştur. ${ }^{51}$

Kaynatılarak jelatinize edilmiş darı, mısır, pirinç veya ince bulgurun hususi laktik kültür ile yirmi dört saat laktik mayalanması neticesinde elde edilen bozada, bir günlük iken \% 03-0,5 nispetinde alkol içerir. Yaz aylarında bozadaki mikroorganizmalar hızla üremekte ve bozayı ekşiterek

48 Serahsî, el-Mebsût, XXIV, 9.

49 Tüketiciler Birliği Genel Başkanı Av. M. Bülent Deniz tarafından, gazozların içeriğinde alkol olup olmadığının tespiti için orijinal ambalajı açılmadan on adet gazoz Gebze'de bulunan TÜBITTAK Marmara Araştırma Merkez'ine teslim edilmiş ve "IFFJ modifiye rebelin metodu 1983" metodu ile etil alkol analizi yapılmış ve bu neticelere varılmıştır. Ayrıntılı bilgi için bk. Rıfat Oral, İstihlak (Helal Gıda Açısından Fiziksel Değişimin Teorik Sonuçları), Uluslararası 2. Helal ve Sağlıklı Gıda Kongresi, Konya, 7-10 Kasım 2013, ed. Fatih Gültekin, (Konya: Aybil Yayınlar1, 2013), ss 492-502.

50 Rıfat Oral, İstihlâk (Glda ve Kozmetik Ürünlerinde Alkol Oranlarının Hükme Tesiri), Uluslararası 1. Helal ve Sağlıklı Gıda Kongresi, Konya, 19-20 Kasım 2011, ed. Fatih Gültekin, Ankara, 2011, 131.

51 http://www.hayrettinkaraman.net/makale/0085.htm (31 Ağustos 2014'te girildi). 
içerisindeki alkol miktarı \% 1'in üzerine çıkmaktadır. Bu sebeple ticari olarak üretilen bozalar pastörize edilip piyasaya sürülmektedir. Taze bozadaki alkol nispeti \% 0,4-0,8 dolaylarındadır. ${ }^{52}$

Kefir, sütteki süt şekerinin (laktoz) süt asidi bakterileri ve kefir taneciği denilen maya yardımıyla parçalanma neticesinde oluşan bir süt ürünüdür. Bu mikroorganizmalar sayesinde hususiyle süt asidi ve bir miktar da etil alkol oluşmaktadır. Geleneksel olarak Orta Asya'da yapılan kefirlerde $\%$ 0,5-0,10 alkol bulunmaktadır. Gıda firmalarının ürettiği kefirlerde ise alkol oranı daha düşük olup \% 0,1-0,5 arasında değişmektedir.

Boza ve kefir uzun süreli inkübasyon ${ }^{53}$ ile alkol nispeti $\%$ 2'nin üzerine çıkabilmektedir. ${ }^{54}$

Ambalajlı ürün şeklinde satılan boza ve kefirler açıldıktan sonra iyi takip edilmeli ve ekşimeden tüketilmelidir. Aksi takdirde alkol oranı yükselmekte ve haram hale gelebilmektedir. ${ }^{55}$

Son günlerde alkolsüz bira adıyla piyasaya çıkan ürün de $\% 0,5$ oranında alkol ihtiva etmektedir. Alkolsüz biraya ismi, gayesi ve Seddi zerîa delili gibi sebeplerden dolayı caizdir denilemez. Alkolsüz birayı alkolsüz şarap veya benzeri ürünlerin takip etmesi ve gençliğin buna düçâr olması korkusu ile hareket edilmelidir. Bazı araştırmacılar isim olarak örneğin malt meyve suyu gibi bir isim ile çıarılması durumunda caiz olabileceğini söylemektedir. ${ }^{56}$ Fakat yine de şüpheli şeylerden kaçmay1 emreden

52 Rıfat Oral, İstihlâk (Gıda ve Kozmetik Ürünlerinde Alkol Oranlarının Hükme Tesiri), 131.

53 İnkübasyon: Bir mikroorganizmanın gelişmesini tamamlaması için belirli bir sıcaklık ve belirli bir atmosfer ortamında tutulma süresi. Ayrıntılı bilgi için bkz http:// hbogm.meb.gov.tr/modulerprogramlar/kursprogramlari/gida/moduller/kefir.pdf (26.09.2014'te girildi.)

54 Rifat Oral, İstihlâk (Glda ve Kozmetik Ürünlerinde Alkol Oranlarının Hükme Tesiri), 131 .

55 Rasulüllah Efendimiz’e (sav) üzüm şerbeti yapılırdı, Efendimiz (sav) ondan içerdi, ertesi gün ve sonraki gün de içerdi, üçüncü gün akşam olduğunda ise o şerbetten içer ve başkasına da ikram ederdi. Fakat kalan olursa ertesi güne bırakmaz onu dökerdi. Bk. Müslim, Eşribe, 9.

56 Murat Şimşek, İslam Hukuku Açısından Karışımlarda İstihlak, Uluslararası 2. Helal ve Sağlıklı Gıda Kongresi, 7-10 Kasım 2013, (Konya: Aybil Yayınları, 2013), 401414, 403.

YIL: 5 SAYI: 9 
dinimizin hassasiyetleri gözetilerek hareket edilmelidir. İçkinin yapıldığı kapların bile kırılmasını emreden Efendimiz'in (sav) izi takip edilerek içkiyi hatırlatan ifadeler yerine onu unutturan ifadeler kullanılmalıdır. ${ }^{57}$ Ekmek hamuruna kıyasla alkolsüz biranın cevazına hüküm vermek ise doğru bir yaklaşım değildir. Ekmek hamurunda bulunan \% 1-3 civarındaki maya neticesinde ortaya çıkan alkol pişirme esnasında buharlaşmaktadır.

Hayreddin Karaman, alkol necis sayılsa bile, imalat esnasında bu maddenin çok miktarda sıvı içine katıldığı ve o sıvıya renk, koku ve tat olarak üstün gelmediği gerekçeleri ile meşrubatta az miktarda alkolün kullanılmasına cevaz verilebileceğini söylemektedir. ${ }^{58}$

Kozmetik ürünlerinde istihlak ile alakalı hususiyle şampuanlarda bulunan alkol benzil olduğu için haram olarak değerlendirilmemektedir. Kolonyadaki alkol hacim esasına göre kolonyanın üzerinde derecesi ile $\mathrm{A}^{\circ}$ olarak ifade edilmektedir. Mesela üzerinde $80^{\circ}$ yazan bir kolonya $\% 80$ alkol ihtiva etmektedir. Bu alkol belli bir süre zarfinda buharlaşıp uçmaktadır. Netice itibariyle alkol uçtuğu ve eser kalmadığı için haram hükmü verilmemiştir. Ancak bütün bunlara rağmen kozmetikte alkolsüz çözümler bulunmalıdır. ${ }^{59}$

İlaç mevzuunda ise mesele biraz farklılaşmakta ve zaruret hali dikkat çekmektedir. Öncelikle alkolün ilaçlarda kullanılması ile alakalı, Ashâb-1 Kiramdan Târık bin Süveyd (ra) ${ }^{60}$ hakkında varid olan hadisi şerif dikkatlerden kaçmamalıdır.

57 Enes bin Mâlik ve Ebû Talha'dan (ra) rivayet olunan Kendilerine şarap miras kalan yetimlerin bu mirası hakkında Efendimiz'e (sav) sorulduğunda "Onu dökün" buyurmuşlar "Sirke yapmayalım mı?" sorusuna ise "Hayır" cevabını vermişlerdir. Bk. Müsnedi Ebî Ya'la, 7, 105, (4051).

58 http://www.hayrettinkaraman.net/makale/0085.htm (31 Ağustos 2014'te girildi).

59 Rıfat Oral, İstihlak (Helal Gıda Açısından Fiziksel Değişimin Teorik Sonuçları), Uluslararası 2. Helal ve Sağlıklı Gıda Kongresi, Konya, 7-10 Kasım 2013, ed. Fatih Gültekin, (Konya: Aybil Yayınları, 2013), ss 492-502

60 Tarık bin Süveyd (ra) Efendimize (sav) şarabı sordu, Efendimiz (sav) şaraptan nehyetti, bunun üzerine Süveyd (ra) "O şifadır." dedi Efendimiz (sav) ise "Hayır o şifa değildir bilakis derttir." buyurdular. Bk. Ebû Dâvud, Tıbb, 11; Beyhâkî, VII, 10, 19676; Müslim. Eşribe, 3. 


\section{$242 \cdot$ YALOVA SOSYAL BILIMLER DERGISI}

Bazı müellifler İmam-1 Ebu Hanife ve Ebu Yusuf'un (rh) üzüm ve hurma kökenli dört alkollü içkinin dışındaki maddelerden elde edilen müskir sıvılarla alakalı ictihadlarının, muhtevasında alkol bulunduran ilaçların hükmüyle alakalı bir ara çözüm sunabileceği üzerine durmuşlardır.

22-24/05/1995 tarihinde Kuveyt'te yapılan el-Munazzametü'l-İslamiyye li'l-Ulûmi't-Tıbbiyye teşkilatı tarafından sekizincisi düzenlenen kongrede alınan tavsiye kararları arasında, tedavi maksadıyla alkol kullanılması hususuna, necasetin manevi olduğu ve koruyucu ya da çözücü olarak alkolün ilaç ve kozmetikte eser (belli belirsiz) miktarda kullanılabileceğine temas edilmiş ve bunda bir beis olmadığına dikkat çekilmiştir. ${ }^{61}$

Helal gida ile alakalı 2013 yılında Konya'da ikincisi yapılan konferansta istihlâk maddesinin netice bildirisinde, ${ }^{62}$ gazlı içeceklerdeki çözücü olarak kullanılan az miktarda etil alkol necis olması sebebiyle helal görülmemektedir. Ayrıca büyük havuz ile alakalı fetvaların bulunması zaruret halini kapsadığı ve şüphe ihtiva ettiği için burada uygulanmaması evlâ olmaktadır. İçki ile soslanmış, marine edilmiş etler pişirilmekle içerisindeki alkol yok olmadığ için temiz değildir. Çünkü alkol etin içine nüfuz etmiştir. Et iki yüz derecede pişen kütle transferi zor ve yavaş bir prosestir. Sulu yolum yapılan tavuk ve kanatlı hayvanların içlerine pislik bulaşma tehlikesi bulunduğu için fetvaya en layık olan kuru yolumun tercih edilmesidir. Necis süt ürünleri, yoğaltım (yoğurt yapma), seyreltim (ayran yapma) veya pıhtılaşma (peynir yapma) yollarıla işlense bile necaset mevcut olduğu için temiz değildir.

Vehbe Zuhaylî İstihlâk'i necis maddenin temiz madde içerisinde kaybolması olarak özetledikten sonra, son kısma misal olarak, hınzır bağırsağından imal edilen anti trombin içeren heparin ilaçlarının (kanın pıhtılaşmasını önleyip akıcılığı sağlayan madde) hastalara günde üç dört sefer yapılan enjeksiyonun günde bir enjeksiyona indirilmesini sağlaması sebebiyle, böbrek yetmezliği, karaciğer lozyonu, kan pihtılaşması, vasküler cerrahi, akut miyokard infarktüsü (kalp krizi) gibi hastalıklarda kullanılan

61 http://shamela.ws/browse.php/book-8356/page-13658\#page-12379 (30.08.2014'te girildi.)

62 Rifat Oral, İstihlak (Helal Gıda Açısından Fiziksel Değişimin Teorik Sonuçları), 492.

YIL: 5 SAYI: 9 
bu madde kimyasal âmiller ve mayalar vasıtasıyla moleküler düzeyde parçalanması ve istihlâk olayının işletilmesi ile cevazına hükmetmektedir. ${ }^{63}$

İslam Tıp Bilimleri Örgütü’nün sekizincisini Mayıs 1995 senesinde Kuveyt'te, dokuzuncusunu Haziran 1997 senesinde Daru'l-Beyza, Kazablanka'da tertip ettiği toplantıda alınan kararlar İstihlaki bir ara çözüm olarak görmektedir. Toplantının sonuç bildirgesinde "İmalatında, suda erimeyen renklendirici ya da koruyucu hususiyeti olan bazı maddeleri eritmek maksadıyla az miktarda da olsa alkol kullanılan gıdaların yenilip içilmesi umumu belvâ bulunduğundan ve yiyecek maddesinin imalat aşamasında eklenen alkolün büyük nispette uçması sebebiyle caizdir" yine "Gıda ve ilaçlara eklenen aslı necis veya haram kılınmış olan maddeler istihale veya istihlak yolu ile helal olur." denilmektedir. ${ }^{64}$

"Bazı Tıbbî Meselelere Tavsiyeler” isimli bildiride istihlak ile alakalı şu maddeler sıralanmıştır;

- Birtakım ilaçlarda aktif maddenin çözülmesi ve incelmesi için kullanılan etil alkol,

- Gıda ve ilaçlarda kullanılan renklendirici ve koruyucuların çözülmesi için kullanılan alkol,

- Pepsin gibi menşei hınzır olan enzimler, maya ve sindirici gibi maddeler ilaç ve gıda içerisinde düşük şekilde istihlake uğraması ve kaybolmasi.

"Bu maddeler çok miktardaki temiz madde içerisinde kaybolduğu ve renk, koku ve tat bakımından izi kalmadığı için helal hükmü verilmelidir." denilmektedir. ${ }^{65}$

Verilen bütün cevazların geçiş dönemlerinde haram maddelerin yerine helalleri ikame edilene kadar ara geçiş dönemi için verilen fetvalar olduğu kanaati ağır basmakta ve doğruya daha yakın gözükmektedir.

63 Vehbe Zuhaylî, Kadâyâ'l-Fıkh Ve'l-Fikr'il-Musâtr, 72.

64 Saffet Köse, Murat Şimşek, Istihlâk, Uluslararası 1. Helal ve Sağlıklı Gıda Kongresi, Konya, 19-20 Kasım 2011, ed. Fatih Gültekin, Ankara, 2011, 123.

65 İbtisam el-Matrafî, et'Tedâvi bi'l-Muharramât, I, 886. 
244 • YALOVA SOSYAL BILIMLER DERGISI

\section{Netice}

İstihlâk ile alakalı fikıh kitaplarının aldığı misaller umumiyetle temizlik bahislerinde geçmektedir. Binânen aleyh gıda ve ilaç gibi mühim bir mevzuu, ibadet temizliği ve necasetin izalesi bahsine kıyas etmek çok doğru bir yaklaşım olmayacaktır. Burada kullanılan ölçüler necasetin izale edilip edilmediğini tespit maksadıyla kullanılmaktadır.

- Mayalar hususunda, elde edildiği kaynağın hınzır olmaması dikkate alınarak hareket edilmesi ve İmam-1 Ebû Hanîfe'nin (rh) görüşünün esas alınması kolaylık ilkesi açısından daha layık gözükmektedir.

- Meşrubatlarda çözücü olarak kullanılan az miktardaki alkol, sarhoş edecek hadde ulaşmadığı müddetçe istihlak (yoğaltım) ile helal olduğu ifade edilmektedir.

- $\quad$ Alkolsüz bira olarak piyasaya arz olunan ürünün sedd-i zerîa ilkesi ve şüpheli şeylerden kaçınmak açısından helal olduğu söylenemez.

- Kozmetik ürünlerinde kullanılan az miktardaki alkol ise, istihlâk ile kaybolmaktadır.

- Kolonya içerisinde bulunan alkol, hava ile teması halinde uçmakta ve helal olarak görülmektedir.

Yapılan araştırmalar neticesinde fiziksel bir değişim olan istihlâkin, genel itibarla içerisindeki haramlığa mevzu olan illet madde yok olmadığ müddetçe helal kılıcı olmadığı yönündedir. 


\section{ISLAM HUKUKUNDA İSTIHLÂK VE HÜKÜMLERI • 245}

\section{KAYNAKÇA}

1- Abdurrahman b. Muhammed b. Süleyman Şeyhîzade (ö.1078/1667), Mecma 'ul-Enhur fi Şerhi Mülteka 'l-Ebhur, Dâru İhyâi't-Türasi'l-Arabî, t.y.

2- Abdulgani b. Tâlib b. Hımâde b. İbrahim el-Ganimi ed-Dımaşki el-Meydânî el-Hanefî (ö.1298/1881), el-Lübâb fi Şerhi'l-Kitab, haz. Muhammed Muhyiddin Abdulhamid, Beyrut, Mektebetü'l-İlmiyye, t.y.

3- Abdülkadir b. Ömer b. Abdülkadir b. Ömer b. Salim et-Tağlibî eş-Şeybânî (ö. 1135/1723), Neylü'l-Mearib bi Şerhi Delili 't-Talib, haz. Muhammed Süleyman Abdullah Aşkar, 1. bs. Kuveyt, Mektebetü'l-Felah, 1403/1983.

4- Ahmed b. Hüseyin b. Ali b. Musa Ebu Bekir el-Beyhakî el-Horasânî el-Husrevcirdî (ö.458/1066), es-Sünenü'l-Kübrâ, haz. Muhammed Abdulkadir Atâ, 3. bs., Beyrut, Dâru'l-Kütübi'l-İlmiyye, 1424/2003.

5- Ahmed b. Muhammed b. Ali el-Feyyumi el-Magri, El-Misbah el-Munir, Lübnan, Mektebetü Lübnan, 1987.

6- Ahmed b. Muhammed b. Ali b. Hacer el-Heysemî (ö.974/1567), Tuhfetu'l-Muhtâc fi Şerhi'l-Minhâc, Misır, Mektebetü'Ticâri el-Kübrâ, 1357/1983.

7- Alâüddin Ebu'l-Hasan Ali b. Süleyman el-Merdâvi ed-Dımaşkî el-Hanbelî (ö. 885/1480), el-İnsaf fi Marifetir-Racihi mine'l-Hılâf, 2. bs., Beyrut, Dâru İhyâi't-Türasi'l-Arabî, t.y.

8- Bâbertî, Muhammed b. Muhammed b. Mahmud Ekmelüddin Ebû Abdullah b. eş-Şeyh Şemsuddin İbnüş-Şeyh Cemalüddin er-Rûmî el-Bâbertî (ö. 786/1384), Inâye Şerhu'l-Hidâye, Dımaşk, Dâru'l-Fikr, t.y.,.

9- Bâhamd b. Muhammed Erfîs, İstihlâkü'l-A'yânü'n-Necise fì Tasni'll-Gizâî, Unmûzecani li Dirâset'il- İnfeha ve'l- Cîlâtîn http://www.islamfeqh.com/Nawazel/ NawazelItem.aspx?NawazelItemID=2028 (24 Ağustos 2014'te girildi.)

10-Cengiz Kallek, "Kulle", TDV İslam Ansiklopedisi (DİA), XXVI, 357.

11-Ebû Abdurrahman Ahmed b. Şuayb b. Ali el-Horasânî en-Nesâî (303/915), es-Sünenü'l-Kübrâ, haz. Hasan Abdülmunim, 1. bs., Beyrut, Müessesetü'r-Risale, $1421 / 2001$.

12-Ebû Bekir b. Ali b. Muhammed el-Haddâdî el-Ibâdî ez-Zebîdî el-Yemenî el-Hanefî (ö.800/1397), el-Cevheretü'n-Neyire, 1. bs. Matbaatu'l-Hayriyye, 1322.

13-Ebû Bekir b. Şeybe Abdullah b. Muhammed b. İbrahim b. Osman el-Absî (ö.235/850), el-Kitabu'l-Musanneffi'l-Ehâdis ve'l-Asâr, haz. Kemal Yusuf, 1. bs., Riyad, Mektebetu'r-Rüşd, 1409.

14-Ebû Davûd Süleyman b. Eş'as b. İshak b. Beşir es-Sicistânî (ö.275/889), Sünen-u Ebî Dâvûd, haz. Muhammed Muhyiddin Abdülhamid, Beyrut, Mektebetü'l-Asriyye, t.y. 


\section{$246 \cdot$ YALOVA SOSYAL BILIMLER DERGISI}

15-Ebû İsa Muhammed b. İsa b. Sevre b. Musa b. Dahhak et-Tirmîzî, el-Camiu'l-Kebîr Sünenu 't-Tirmîzî, haz. Beşşar Maruf, Beyrut, Dâru'l-Garbi'l-İslâmî, 1998.

16-Ebû Muhammed Mahmud b. Ahmed b. Musa b. Ahmed b. Hüseyin el-Ğitabi el-Hanefî Bedruddin (ö.855/1451), Minhatu's-Sülûk fì Şerhi Tuhfetu'l-Mülûk, haz. Ahmed Abdurrezzâk, 1. bs., Katar, Vüzerâti'l-Evkâf ve'ş-Şüûni'l-İ̀slâmiyye, 2007/1428.

17-Ebû'l-Mealî Burhanuddin Mahmud b. Ahmed b. Abdulaziz b. Ömer b. Mâze elbuhârî el-Hanefî (ö.616/1219), el-Muhıtu'l-Burhânî fi'l-Fıkhi'n-Numânî Fıkhı'l-İmamı Ebî Hanîfe Radıyallâhu anh, haz. Abdulkerim Sâmî el-Cundî, 1. bs., Beyrut, Dâru'l-Kütübi'l-İlmiyye, 2004/1424.

18-Ebû Ya'lâ Ahmed b. Ali bin Yahya b. İsa et-Temimî el-Mevsılî (307/920), Müsned-i Ebî Ya'lâ, haz. Huseyin Selim Esed, 1. bs., Dımaşk, Dâru'l-Me'mûn li't-Turâs, 1404.

19-Fahruddin ez-Zeylaî, Osman b. Ali el-Bâriî ez-Zeylaî el-Hanefî (ö.743/1343), Tebyinu'l-Hakâlk Şerhu Kenzi'd-Dekâik, 1. bs., Kahire, el-Matbaatü'l-Kübra el-Emiriyye, 1313.

20-Firuzâbâdî, Ebu’t-Tâhir Mecdüddin Muhammed b. Yakub Firuzâbâdî (ö817-), el-Kâmûs'ul-Muhît, haz. Enes Muhammed eş-Şamî, Zekeriya Cabir Ahmed, Kahire, Daru'l-Hadis, 1429/2008.

21-Haskefî, Muhammed b. Ali b. Muhammed el-Maruf Alaüddin el-Haskefî el-Hanefî (ö.1088/1677), ed'Dürrü'l-Muhtar Şerhu Tenvîri'l-Ebsar ve Câmiu'l-Bihar, haz. Abdülmun'im Halil İbrahim, 1. bs., Lübnan, Daru'l-Kütübi'l-İlmiyye, 1423/2002.

22-Halef b. Ebi Kasım Muhammed el-Ezdî el-Kayrevânî el-Mâlikî, et-Tehzîb fî İhtisari'l-Müdevvene, haz. Muhammed Emin, 1. bs., Dubai, Dâru'l-Buhus lid'Ddirâseti'l-İslamiyye ve İhyai't-Türas, 2002/1423.

23-http://www.hayrettinkaraman.net/makale/0085.htm (31 Ağustos 2014'te girildi.)

24-http://shamela.ws/browse.php/book-8356/page-13658\#page-12379 (30.08.2014'te girildi.)

25-İbn Abdilberr, Ebû Ömer Yusuf b. Abdullah b. Muhammed b. Abdilberr b. Asım el-Kurtûbî (ö.463/1071), el-Kâfi fí Flkhi Ehli'l-Medine, haz. Muhammed Muhammed el-Moritânî, 2. bs., Rıyad, Mektebetu'r-Riyad el-Hadîse, 1400/1980.

26-İbn Âbidîn, Muhammed Emin b. Ömer b. Abdülaziz Âbidin ed-Dımışkî elHanefî (ö.1252), Reddü'l-Muhtâr ale'd-Dürr'i-lMuhtar, 2. bs, Beyrut, Dâru'l-Fikr, $1412 / 1992$.

27-İbn Hazm ez-Zâhirî, el-İmam Allame Ebu Muhammed Ali b. Ahmed b. Said b. Hazm el-Endülüsî, el-Muhalla fi Şerhi'l-Mücella bi'l-Hucec ve'l-Asar, haz. Hassan Abdulmennan, Riyad, Beyt'ul-Fikri'd-Devliyye, t.y.

28-İbn Hümâm, Kemalüddin Muhammed b. Abdülvahid es-Sivâsî b. Hümam (861/1457), Fethu'l-Kadîr, Dâru'l-Fikir, t.y.

YIL: 5 SAYI: 9 
29-İbn Kudâme el-Makdisî, Ebû Muhammed Muvaffikuddin Abdullah b. Ahmed b. Muhammed b. Kudâme el-Makdisî el-Hanbelî (620/1223), el-Muğnî li İbn Kudâme, Kahire, Mektebetü Kahire, 1388/1968.

30-İbn Kudâme el-Makdisî, Ebû Muhammed Muvaffikuddin Abdullah b. Ahmed b. Muhammed b. Kudâme el-Makdisî el-Hanbelî (620/1223), eş-Şerhu'l-Kebîr alâ Mütüni 'l-Mukni', haz. Muhammed Reşit Rıza, Dâru'l-Kitabi'l-Arabî lin'Neşr ve't-Tevziğ, t.y.

31-İbn Manzûr, Ebu'l-Fadl Cemaluddin Muhammed b. Mükerrem el- Ensârî (ö711/1311) Lisânü'l-Arab, Kâhire, Dâru'l-Maârif, 1119/1707.

32-İbn Nüceym, Zeynuddin b. İbrahim b. Muhammed b. Nüceym el-Mısrî, el-Bahru'r-Râik Şerhu Kenzi'd-Dekâık, 2. bs., Dâru'l-Kitabi'l-İslâmî, ty.

33-İbn Teymiye, Ahmed b. Abdulhalim, Mecmû'ul-Fetâvâ, haz. Abdurrahman bin Muhammed bin Kasım ve İbnuhu Muhammed, Medine, Mücemmer'l-Melik Fahd li Tabaati'l-Mushafi'ş-Şerif, 1425/2004.

34-İbtisam el-Matrafî, et'Tedâvi bi'l-Muharramât, es-Sicillü'l-İlmî li Mü'tmer el-Fikhi'l-İslâmi's-Sani, Kazâya Trbbiyye Muâssra, Camiatü'l-İmam Muhammed bin Suûd'il-İslamiyye, Riyad, 1431/2009.

35-Kâsânî, Alâuddin Ebu Bekir b. Mes'ûd b. Ahmed el-Kâsânî el-Hanefî (ö.587/1191), Bedâiu's-Sanâî fì Tertibi'ş-Şerâi, Dâru'l-Kütübi'l-İlmiyye, 1406/1986.

36-Mahfûz bin Ahmed b. Hasan Ebû'l-Hattab el-Kulûzânî, el-Hidâye alâ Mezhebi Ahmed bin Hanbel eş-Şeybânî, haz. Mâhir Yasin, 1. bs. Müessesetü Ğaras lin-Neşr ve't-Tevziğ, 1425/2004.

37-Mâverdî, Ebu'l-Hasan Ali b. Muhammed b. Muhammed b. Hbib el-Basrî el-Bağdadi el-Maverdî (ö.450/1058), el-Hâvi'l-Kebir fí fikhi Mezhebi İmami'ş-Şafî̀ Şerhu Muhtasarı'l-Müzenî, haz. Şeyh Ali Muhammed, 1. bs., Beyrut, Dâru'l-Kütübi'l-İlmiyye, 1419/1999.

38-Mergînânî, Ali b. Ebi Bekr b. Abdulcelil el-Fergânî el-Mergınânî (ö.593/1197), el-Hidâye fì Şerhi Bidayeti'l-Mübtedî, haz. Talal Yusuf, Beyrut, Dâru İhyâi't-Türasi'l-Arabî, t.y.

39-Mevsîlî, Abdullah b. Mahmud b. Mevdûd el-Mevsılî (ö.683/1284), İhtiyar li Ta'lili'l-Muhtar, haz. eş-Şeyh Mahmud Ebû Dekîka, Kahire, Matbaatü'l-Halebî, 1356/1937.

40-Muhammed b. Ahmed ed-Dusûkî el-Mâlikî (1230/1815), Haşiyetü'd-Düsükî ala'ş-Şerhi'l-Kebîr, Dâru'l-Fikr, t.y.,.

41-Muhammed b. Ahmed b. Ebi Ahmed Ebu Bekir Alaüddin es-Semerkandî (ö.450/1140), Tuhfetü'l-Fukahâ, 2. bs., Lübnan, Dâru'Kütübi'İlmiyye, 1414/1994.

42-Muhammed b. İsmail Ebû Abdullah el-Buhârî (ö.256/870), el-Câmiu'l-Müsnedü 's-Sahihu'l-Muhtasar min Umûri Rasulillah Sallallahu Aleyhi ve Sellem ve Sünenihi ve Eyyâmihi, haz. Muhammed b. Nasır Nasır, 1. bs., Dâru Dûki'n-Necât, 1422. 


\section{8 - YALOVA SOSYAL BILIMLER DERGISI}

43-Muhammed Ravvâs Kal'aci, Mu'cemu Lugati'l-Fukaha, 2. bs., Beyrut, Dâru'n-Nefâis, 1988.

44-Murat Şimşek, İslam Hukuku Açısından Karışımlarda İstihlak, Uluslararası 2. Helal ve Sağlıklı Gıda Kongresi, 7-10 Kasım 2013, Konya, Aybil Yayınları, 2013.

45-Müslim b. Haccâc Ebû'l-Hasan el-Kuşeyrî en-Nisâbûrî (ö.261/875), el-Müsnedü's-Sahih el-Muhtasar bi nakli'l-Adl ani'l-Adl ila Rasulillah Sallallahü Aleyhi ve Sellem, Muhammed Fuad Abdulbakî, Beyrut, Dâru İhyâi’t-Türâsi'l-Arabî, t.y.

46-Nezîh Hammad, el-Edviyet'ul-Müstemile 'ale'l-Kûhul ve'l-Muhadderât, Mecelletü Mecma'1l- F1khi'l-İslâmî, Y11:14, Sayı:16.

47-Nezîh Hammad, el-Mevâddü'l-Muharreme ve'n-Necise fi'l-Giza ve'd-Devâ beyne'n-Nazariyye ve't-Tatbîk, Dimaşk, 2003.

48-Orhan Çeker, İstihale, I. Ulusal Helal ve Sağlıklı Gıda Kongresi, Sözlü Bildiriler, 19-20 Kasım 2011, Ankara, ed. Fatih Gültekin, Ankara, 2011.

49-Rıfat Oral, İstihlâk (Gıda ve Kozmetik Ürünlerinde Alkol Oranlarının Hükme Tesiri), Uluslararası 1. Helal ve Sağlıklı Gıda Kongresi, Konya, 19-20 Kasım 2011, ed. Fatih Gültekin, Ankara, 2011.

50-Rıfat Oral, İstihlak (Helal Gıda Açısından Fiziksel Değişimin Teorik Sonuçları), Uluslararası 2. Helal ve Sağlıklı Gıda Kongresi, Konya, 7-10 Kasım 2013, ed. Fatih Gültekin, Konya, Aybil Yayınları, 2013 ss 492-502.

51-Saffet Köse, Murat Şimşek, İstihlâk, Uluslararası 1. Helal ve Sağlıklı Gıda Kongresi, Konya, 19-20 Kasım 2011, ed. Fatih Gültekin, Ankara, 2011, 123.

52-Serahsî, Muhammed b. Ahmed b. Ebî Sehl Şemsü'l-E'imme Serahsî, el-Mebsût, Beyrut, Dâru'l-Marife, 1414/1993.

53-Şirbînî, Şemsüddin Muhammed b. Ahmed el-Hatîb eş-Şirbînî eş-Şafî̂ (ö.977/1570), Muğnî'l-Muhtâc ilâ Marifeti Meâni Elfâzi'l-Minhâc, 1. bs., Beyrut, Daru'l-Kütübi'l-İlmiyye, 1994/1415.

54-Tahtâvî, Ahmed b. Muhammed b. İsmail et-Tahtâvî el-Hanefî̀ (ö.1231/1816), Hâşiyetü't-Tahtâvî alâ Merâkı'l-Felâh Şerhu Nûri'l-Îzâh, haz. Muhammed Abdülaziz el-Hâlidî, 1. bs., Beyrut, Dâru'l-Kütübi'l-İlmiyye, 1997/1418.

55-Vehbe Zuhaylî, Kadâyâ'l-Fıkh Ve'l-Fikr'il-Musâır, 1. bs., Dımaşk, Dar'ul-Fikr, 2006.

YIL: 5 SAYI: 9 